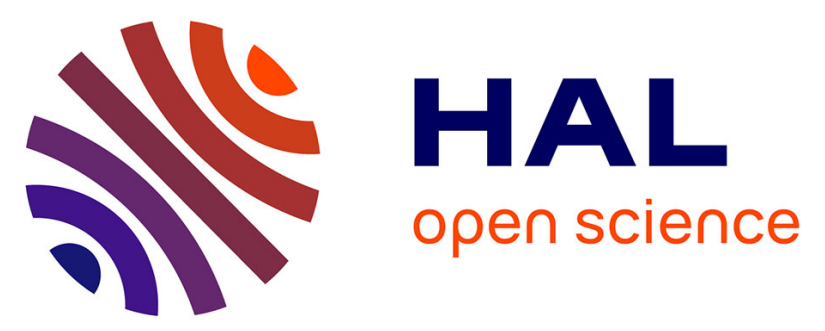

\title{
Safety Evaluation of Food contact paper and board using Chemical Tests and in vitro Bioassays-The role of known and unknown substances
}

Ulla Honkalampi-Hämäläinen, Emma Bradley, Laurence Castle, Isabelle Séverin, Laurence Dahbi, Olof Dahlman, Jean-Claude Lhuguenot, Maria A Andersson, Pasi Hakulinen, Douwe Hoornstra, et al.

\section{To cite this version:}

Ulla Honkalampi-Hämäläinen, Emma Bradley, Laurence Castle, Isabelle Séverin, Laurence Dahbi, et al.. Safety Evaluation of Food contact paper and board using Chemical Tests and in vitro BioassaysThe role of known and unknown substances. Food Additives and Contaminants, 2010, 27 (03), pp.406415. 10.1080/19440040903401358 . hal-00573087

\section{HAL Id: hal-00573087 https://hal.science/hal-00573087}

Submitted on 3 Mar 2011

HAL is a multi-disciplinary open access archive for the deposit and dissemination of scientific research documents, whether they are published or not. The documents may come from teaching and research institutions in France or abroad, or from public or private research centers.
L'archive ouverte pluridisciplinaire HAL, est destinée au dépôt et à la diffusion de documents scientifiques de niveau recherche, publiés ou non, émanant des établissements d'enseignement et de recherche français ou étrangers, des laboratoires publics ou privés. 


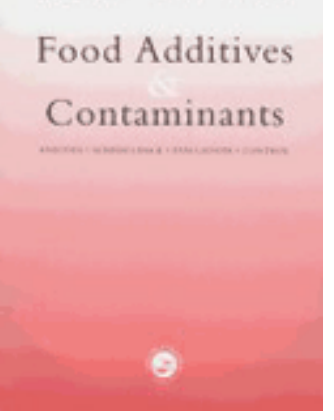

\section{SAFETY EVALUATION OF FOOD CONTACT PAPER AND BOARD USING CHEMICAL TESTS AND IN VITRO BIOASSAYS - THE ROLE OF KNOWN AND UNKNOWN SUBSTANCES}

\begin{tabular}{|c|c|}
\hline Journal: & Food Additives and Contaminants \\
\hline Manuscript ID: & TFAC-2009-008.R1 \\
\hline Manuscript Type: & Original Research Paper \\
\hline $\begin{array}{r}\text { Date Submitted by the } \\
\text { Author: }\end{array}$ & 05-Oct-2009 \\
\hline Complete List of Authors: & $\begin{array}{l}\text { Von Wright, Atte; University of Kuopio, Department of Biosciences } \\
\text { Bradley, Emma; Central Science Laboratory, Food Safety \& Quality } \\
\text { Honkalampi-Hämäläinen, Ulla; University of Kuopio, Department of } \\
\text { Biosciences } \\
\text { Castle, Laurence; Defra-CSL; Defra-CSL } \\
\text { Weber, Assi; KCL Science and Consulting } \\
\text { Salkinoja-Salonen, Mirja; University of Helsinki, Department of } \\
\text { Applied Chemistry and Microbiology } \\
\text { Andersson, Maria; University of Helsinki, Department of Applied } \\
\text { Chemistry and Microbiology } \\
\text { Hoornstra, Douwe; University of Helsinki, Department of Applied } \\
\text { Chemistry and Microbiology } \\
\text { Lhuguenot, Jean-Claude; Université de Bourgogne, Food Toxicology } \\
\text { Laboratory } \\
\text { Severin, Isabelle; Université de Bourgogne, Food Toxicology } \\
\text { Laboratory } \\
\text { DAHBI, Laurence; Université de Bourgogne, Toxicology; ENSBANA, } \\
\text { Toxicology } \\
\text { Stammati, Annalaura; Istituto Superiore di Sanita, Department of } \\
\text { Environment and Primary Prevention } \\
\text { Dahlman, Olof; STFI-Packforsk AB } \\
\text { Turco, Laura; Istituto Superiore di Sanita, Department of } \\
\text { Environment and Primary Prevention } \\
\text { Zucco, Flavia; Consiglio Nazionale delle Richerche, Istituto } \\
\text { Neurobiologia e Medicina Molecolare }\end{array}$ \\
\hline
\end{tabular}




\section{SCHOLARONE ${ }^{m}$ Manuscripts}




\begin{abstract}
In vitro toxicological tests have been proposed as an approach to complement the chemical safety assessment of food contact materials, particularly those with a complex or unknown chemical composition such as paper and board. Among the concerns raised regarding the applicability of in vitro tests are the effects of interference of the extractables on the outcome of the cytotoxicity and genotoxicity tests applied and the role of known compounds present in chemically complex materials such as paper and board, either as constituents or contaminants. In order to answer these questions, a series of experiments were performed to assess the role of, natural substances (wood extracts, resin acids), some additives (diisopropylnaphthalene, phthalates, acrylamide, fluorescent whitening agents) and contaminants (2,4-diaminotoluene, benzoa(a)pyrene) in the toxicological profile of paper and board. These substances were individually tested or used to spike actual paper and board extracts. The toxic concentrations of diisopropylnaphthalenes and phthalates, were compared with those actually detected in paper and board extracts showing conspicuous toxicity. According to the results of the spiking experiments the extracts did not affect the toxicity of tested chemicals, nor was there any significant metabolic interference in the cases where two compounds were used in tests involving xenobiotic metabolism by the target cells. While the identified substances apparently have a role in the cytotoxicity of some of the project samples, their presence does not explain the total toxicological profile of the extracts. In conclusion, in vitro toxicological testing can have a role in the safety assessment of chemically complex materials in detecting potentially harmful activities not predictable by the chemical analysis alone.
\end{abstract}




\section{INTRODUCTION}

Paper and board materials intended for food contact applications are chemically complex materials. Because of their long history of use, the manufacturing processes used, and the fact that they are made mainly from naturally-occurring raw materials, paper and board has a good reputation with the consumer. Whilst there are either regulations or recommendations in some individual Member States of the European Union (EU), there are no specific EU-harmonised Directives or Regulations on paper and board. Rather, the general Framework Regulation No. (EC) $1935 / 2004$ is invoked. The central provision applying to all food contact materials is the following:

"Materials and articles must be manufactured in compliance with good manufacturing practice so that, under their normal or foreseeable conditions of use, they do not transfer their constituents into foodstuffs in quantities which could either endanger human health or bring about an unacceptable change in the composition of the foodstuffs or deterioration in the organoleptic characteristics thereof".

To demonstrate this is a challenge. Whereas chemical analysis is used to test plastics for the migration of known constituents such as monomers and additives into foods or food simulants, chemical analysis is less informative in the case of materials like paper and board which can contain a large number of both known and unknown substances. Testing by bioassay of the global (total) extract or migrate from paper/board can complement chemical analysis by providing additional information. The toxicological screening tests that could be applied to paper and board food contact materials have been reviewed recently [von Wright, 2007]. 
The EU project BIOSAFEPAPER (QLK1-CT-2001-00930) was designed to address the safety aspects of food contact paper and board by in vitro toxicological screening or checking, whether sufficient amounts of substances would migrate to a selected food simulant to elicit a biological response in short term bioassays in conditions mimicking the actual consumer exposure. The cytotoxicity and genotoxicity assays selected for this purpose have been described [Bradley et al., 2008].

The ethanol extract of two board samples, designated NSP4 (a non food grade material) and NSP5 proved to be strongly cytotoxic and the former also mutagenic in the Ames test [Bradley et al., 2008]. In the chemical analysis the majority of the identified extractables in NSP4 were diisopropylnaphthalene (DiPN) isomers, alkanes, different phthalates and resin acids, while in NSP5 the most abundant identified compound was 1-methyl-2-pyrrolidinone (Table 1).

The purpose of the experiments described in this paper was to examine the role of the identified substances in the toxicity of the NSP4 extract. Additionally, the responses of the tests to either natural constituents of the raw materials for paper and board manufacture, substances used for special technical purposes (fluorescent whitening agents or FWAs) or different contaminants were examined. These substances were tested as such and they were also used to spike actual extracts of paper and board in order to find out the eventual interactions between them and other extractables present in the samples. 


\section{Materials and methods}

\section{Test substances}

Spruce wood water extract. Spruce wood meal (5 g) was extracted by shaking with $100 \mathrm{ml}$ water at $50^{\circ} \mathrm{C}$ for $4 \mathrm{~h}$. The extract was filtered and stored refrigerated before use, to prevent microbial growth. A portion was evaporated to dryness and this revealed that the extract contained ca. $7.0 \mathrm{~g} \mathrm{~L}^{-1}$ of dry matter. Spruce wood ethanol extract. Spruce wood meal (5 g) was extracted by shaking with $100 \mathrm{ml}$ ethanol at room temperature for $4 \mathrm{~h}$. The extract was filtered and stored refrigerated. It contained $1.2 \mathrm{~g} \mathrm{~L}^{-1}$ dry material.

Other chemicals. The tetra-sulpho and the disulpho-stilbene FWAs were from Bayer (supplied as $40 \mathrm{~g} \mathrm{~L}^{-1}$ aqueous solutions by the paper industry partners in the project). 2,4Diaminotoluene (98\%), dibutylphthalate (DBP, 99+\%) and di(2-ethylhexyl)phthalate (DEHP, 99+\%) were from Aldrich (Gillingham, UK). Diisobutylphthalate (DiBP, Bisoflex, commercial plasticiser, ex. BP Chemicals Ltd., London UK, no purity given) was provided by FERA. Acrylamide (>99\%) and benzo(a)pyrene (B(a)P, were from Sigma (Poole, UK). Diisopropylnaphthalenes (DiPNs, isomeric mixture, 'reagent grade') was from Fisher (Loughborough, UK). Dehydroabietic acid was a technical grade sample available within STFI. Analysis by GC-MS revealed that it constituted 95\% dehydroabeitic acid and three other minor resin acids made up the remaining 5\%. For the cytotoxicity tests the compounds were dissolved either in DMSO (phthalates, DiPNs,) or methanol (acrylamide, 2,4diaminotoluene, and for the genotoxicity assays in DMSO.

\section{Paper and board extracts for spiking experiments}

A cold water extract from recycled test liner (BSP5), prepared according to EN 647 standard, and an ethanol extract from bleached kraft (BSP9), prepared according to pre-standardization 
method ENV 1186-15, were used in spiking experiments with acrylamide. The total content of migrants in the respective final extracts was $16.1 \mathrm{mg} \mathrm{L}^{-1}$ (BSP5) and $46 \mathrm{mg} \mathrm{L}^{-1}$ (BSP9). These extracts were selected because of their low toxicity in preliminary cytotoxicity assays. The water extract of uncoated SBS (Solid Bleached Sulfate) NSP11, because of its high content of extractables ( $472 \mathrm{mg} \mathrm{L}^{-1}$ ), and the ethanol extract of NSP4, because of its high cytotoxicity [details of these extracts, see Bradley et al. 2008], were selected for spiking with B(a)P and DiPNs.

\section{METHODS}

\section{Cytotoxicity assays}

Tests with human larynx carcinoma cell line (HEp-2) and metabolically competent mouse hepatoma cell line (Hepa-1c1c7). The tests were performed as described in detail by Severin et al. [2005] and Bradley et al [2008] using either the total protein content (TPC) or the neutral red uptake (NRU) as endpoints, the former with Hepa-1c1c7 cells and the latter with HEp-2 cells.

RNA-synthesis inhibition test with HepG2 cells. The in vitro RNA synthesis inhibition was measured by an automated test as a 30 min kinetic measurement of the uptake of tritiated uridine into the cellular macromolecules, as described by Severin et al. [2005].

Inhibition of boar spermatozoan motility. The extended boar semen, a commercial product obtained from an artificial insemination station, contained $27 \times 10^{6}$ spermatozoa per $\mathrm{mL}$. It contained 2 - $5 \mathrm{mM}$ of extracellular potassium and 150 - $200 \mathrm{mM}$ sodium. The extended semen was exposed to $1 \mathrm{vol} \%$ of the test substance or its dilutions for 1 to 4 days at room temperature, after which the inhibition of sperm motility was assessed [Andersson et al. $1998]$.

\section{Genotoxicity assays}


Ames test. The standard Ames test [Maron and Ames, 1983] based on histidine auxtrophic Salmonella typhimurium strains TA98, TA100, and TA97 was performed on the following chemicals: acrylamide $(10 \mu \mathrm{g}-10 \mathrm{mg} /$ plate $) ; 2,4-$ diaminotoluene (2.5 - $2000 \mu \mathrm{g} / \mathrm{plate})$; phthalate mixture $(5 \mu \mathrm{g}-500 \mu \mathrm{g} / \mathrm{plate})$; DiPNs $(5 \mu \mathrm{g}-500 \mu \mathrm{g} / \mathrm{plate})$; disulpho-stilbene $(5 \mu \mathrm{g}$ $-500 \mu \mathrm{g} /$ plate $)$; tetrasulpho-stilbene $(5 \mu \mathrm{g}-500 \mu \mathrm{g} / \mathrm{plate})$.

The S-9 preparation for metabolic activation system was either a commercial preparation (IFFA CREDO, L’ Arbresle, France) or was obtained from phenobarbital//-naphtoflavoneinduced rat liver prepared by the National Laboratory Animal Center, University of Kuopio. Both microsomal preparations were found to perform equally with routine positive controls (data not shown).

Comet assay with HepG2 cells. The in vitro Single Cell Gel/Comet assay was performed as described by Bradley et al. [2008]. Since HepG2 cells are metabolically competent, no metabolic activation was needed. Briefly, the HepG2 cells were grown in conditions identical to those applied for the RNA-synthesis inhibition test. For the test, six wells of a 96-well tissue culture plate per concentration were seeded with $5 \times 10^{4}$ cells in $0.2 \mathrm{ml}$ of the culture medium. After 20 hours of incubation, the cells were treated with the test substance for 20 hours.

After the exposure, the cells mixed in $75 \mu \mathrm{l}$ of low-melting point agarose, spread on slides pre-coated with normal melting point agarose. After cell lysis an electrophoresis was performed followed by staining of DNA and analysed. Olive tail moment (OTM, a measure of tail length $\mathrm{x}$ a measure of DNA in the tail) was used as the metric to characterise the DNA damage in individual cells. The analysis was done using an automated image analysis system (Comet, version 4; Kinetic Imaging, UK). A total of 100 (50 per slide) individual comets were analysed per sample. 


\section{RESULTS}

\section{The cytotoxicities of the tested chemicals or extracts}

The results of the different cytotoxicity assays are summarized in Table 2 . It can be seen that there was a general agreement between the acute cytotoxicity tests and RNA synthesis inhibition test with the exception of spruce wood extracts. Also the outcome of the boar spermatozoan motility inhibition assay agreed with the traditional cytotoxicity assays. The spruce wood extracts generally showed only marginal toxicity (mainly in HEp2 cells). Of the different pure substances tested on the mammalian cells the most toxic was 2,4diaminotoluene followed by acrylamide, tetrasulpho-stilbene and then disulpho-stilbene FWAs. The DiPNs mix was consistently more toxic than the phthalate mixture (it should be noted that in this case the results are expressed as microgram per millilitre and not as molar toxicities due to practical reasons). The hepatic cell lines had a different sensitivity to some of the test agents from that of the Hep-2 cell line. Compounds like 2,4-diaminotoluene and FWAs were more toxic to HepG2 and Hepa-1c1c7 cells than to Hep-2 cells, while the opposite was true with DiPNs and phthalates.

\section{Tests on spiked paper and board samples}

Acrylamide spiked extracts.The effect of paper and board extracts on the cytotoxicity of acrylamide was tested in Hepa-1 cells and in the RNA synthesis inhibition test with HepG2 cells. Also the inhibitory concentrations for the boar spermatozoan motility were determined.

The spiking of paper and board extracts with acrylamide did not produce any major effect on the toxicity of the substance in most of the tests (Table 3). Some synergistic action could be seen in boar spermatozoan motility inhibition assay with BSP9 ethanol extract. Generally, the 
differences probably reflect the normal fluctuation of biological test systems rather than actual different response.

The positive response of acrylamide in comet assay was not affected by the extractables present in water extract of BSP5 or ethanol extract of BSP9 (data not shown).

$B[a] P$ spiked extracts. As NSP4 ethanol extract was cytotoxic in the RNA synthesis inhibition assay [Bradley et al., 2008], it was tested in the comet assay at the concentration which induces a 50\% decrease of the RNA synthesis in order to avoid false positive response in genotoxicity due to cell death by apoptosis or necrosis.

A dose-dependent increase of the genotoxic effect due to $\mathrm{B}[\mathrm{a}] \mathrm{P}$ was observed. The effect was not influenced by the solvent (NSP4 extract versus ethanol or NSP11 extract versus water). However, the effect of DiPNs was variable. With NSP4, DiPNs did not influence the results at the lowest concentration of $\mathrm{B}[\mathrm{a}] \mathrm{P}(1 \mu \mathrm{M})$, but a decrease of the genotoxicity appeared in cells treated with DiPNs together with 5 or $10 \mu \mathrm{M}$ of B[a]P (Figure 1). With NSP11, a slight increase in genotoxicity appeared at $6.25 \mu \mathrm{M}$ B[a]P when tested together with DiPNs, but there was no effect at lower B[a]P concentrations (Figure 2). 


\section{DISCUSSION}

\section{Rationale for the selection of the control substances tested}

Spruce wood extracts. Hot water and ethanol extracts of spruce wood were chosen to represent the complex mixtures of natural substances potentially present in paper and board and which might interfere with the outcome of the toxicity tests performed on paper and board samples. Among the most abundant substance classes identified by GC-MS were lignans $(9 \%)$, resin acids (8\%), fatty acids (1\%) and various alkanols (3\%) (data not shown). However, only about $20 \%$ of the organic material in the water extract could be identified by GC-MS.

Dehydroabeitic acid. Dehydroabietic acid was chosen as a representative of the natural resin acids which are normal constituents of wood. Natural resins are water-insoluble mixtures of substances, many of which have a hydroaromatic structure. Some resin acids are toxic to insects, moulds and fungi and protect the wood from attack. Depending on the paper-making process used, most resin acids are released and removed in the spent pulping process liquor. In a small survey, total amounts of dehydroabeitic acid and abeitic acid were up to $1 \mathrm{mg} \mathrm{g}^{-1}$ $(0.1 \%)$ in the samples tested [Ozaki et al., 2005]. The same authors reported that dehydroabeitic acid and abeitic acid were positive in the in vitro rec assay.

Fluorescent whitening agents (FWAs). Di- and tetra-suphostilbenes were used as examples of FWAs because of their widespread use to enhance the brightness of paper and board - FWAs are also know as optical brighteners. Approximately $80 \%$ of FWAs used in paper and board manufacture are based on stilbene derivatives. They are quite planar/linear molecules with extensive delocalised $\pi$ electron systems and one or more sulphonic acid groups [Roberts, 1991] The tetra-sulpho stilbenes are by far the most commonly found whereas the hexa- 
sulphos are rarely if ever used because they are too water soluble and so are not retained on the paper fibres to exert the effect intended. For these reasons, a tetra-sulpho and a di-sulphostilbene were selected as test substances. The substances selected are on the positive list of FWAs accepted in the French regulations, the Italian regulations and also are on the list of substances of the Council of Europe Resolution on Paper and Board [COE, 2002].

Diisopropylnaphthalene. Diisopropylnaphthalene (DiPN) was selected because it can be considered as a typical process contaminant present in paper and board.

Diisopropylnaphthalenes are isomeric mixtures in which the 2,6- form is the dominant dialkylated isomers. DiPN was first detected in food packaging samples in 1994 [Sturaro et al., 1994] and originates mainly from the presence of carbonless copy papers in paper recovered for recycling. Levels in paper/board can be in the range 2 to $60 \mathrm{mg} \mathrm{kg}^{-1}$ [Bebiolka et al., 1997; MAFF 1999; Zhang et al., 2008]. DiPN has a boiling point of $290-300^{\circ} \mathrm{C}$ and is virtually insoluble in water but is freely soluble in fats and organic solvents such as ethanol [RKS 1998]. Although DiPN itself is relatively non-toxic, DiPN was included to test for any metabolic interference - e.g. saturation effects with competitive inhibition preventing the potent activity of $\mathrm{B}(\mathrm{a}) \mathrm{P}$ being displayed.

Acrylamide. Acrylamide is the starting substance used to make very high molecular weight polyacrylamides used in paper-making as wet-strength agents and as retention aids. Attention focussed on acrylamide in 2002 when it was discovered that it could form from normal food components when many foods are cooked at high temperature. The polyacrylamides used in papermaking have either extremely low or usually even not-detectable residues of unreacted acrylamide. Consequently, acrylamide is generally not detectable in paper/board [FSA, 2002] 
and worst-case migration calculations are all well below the migration limit set for plastics of 'not detectable', less than $10 \mu \mathrm{g} \mathrm{kg}^{-1}$ food.

Phthalates. Like DiPN, phthalates were selected because they can be considered as a typical process contaminants present in paper and board. Phthalates are a family of chemical with different toxicological properties. They are ubiquitous environmental contaminants and they may find their way into paper/board particularly from their use in printing inks and glues (adhesives) that are not completely removed from recovered paper used in recycling. By far the most common phthalates encountered are DiBP, DBP and DEHP. They typically occur in a ratio that is rather constant at ca. $4: 1: 1$.

2,4-Diaminotoluene and Benzo(a)pyrene. These were chosen to represent typical widelyoccurring environmental pollutants of two classes; aromatic amines and polycyclic aromatic hydrocarbons respectively. They are not expected to contaminate Paper/Board samples but their toxic properties have been investigated thoroughly and so they were included as positive-control substances of interest.

\section{The responses of the different cytotoxicity assays to the test substances}

In general there was a good agreement between the results of different mammalian cytotoxicity tests, including the boar spermatozoan motility inhibition assay. Spruce wood extracts showed some toxicity in the RNA-synthesis inhibition assay, but were generally negative in other cytotoxicity tests, with the exception of the water extract and the Hep-2 cells. The special sensitivity of this cell line in comparison to the hepatic cell lines used in other tests may result from the lack of active detoxification mechanisms present in the liver cells. 


\section{The toxicological profile of the test compounds}

\section{Wood-associated substances}

Both water and ethanol extracts of spruce wood evoked some toxic responses, mainly in the RNA synthesis inhibition assay measuring sublethal effects, the water extract also showing some cytotoxicity in Hep-2 cells (Table 2). In contrast, dehydroabietic acid, which was the most abundant identified wood-associated compound in the actual sample was consistently non-toxic at the tested concentrations. The water extracts of paper and board tested by us have been consistently non-toxic and also ethanol extracts showed a wide variation in the toxicity, some showing only marginal activity [Bradley et al. 2008] . Thus, while there apparently are bioactive compounds present in wood, their eventual presence in paper and board does not interfere with the toxicological testing.

\section{The cytotoxic profile of DiPNs and phthalates}

DiPNs and phthalates were among the clearly cytotoxic substances identified in this study. Especially the toxicity of phthalates was more pronounced in Hep-2 cells lacking an efficient xenobiotic metabolism, in comparison to metabolically competent hepatic cell lines. This indicates some metabolic detoxicification of these types of compounds.

DiPNs have been considered as a safe alternative for polychlorinated biphenyls in carbonless copy papers due to its reported low toxicity, which apparently results from the metabolic oxidation of the isopropyl side chain rather than the aromatic ring [Höke and Zellerhof 1998]. No recent reports of either cytotoxcity or genotoxicity of DiPNs have been published, and while, according to the results reported here, there are no indications of genotoxic concerns, the migration of amounts approaching the cytotoxic levels into foods or simulants remains a possibility. 
Phthalates have attracted attention as endocrine disruptors and reproductive and developmental toxicants. Their cytotoxic properties have not been systematically studied, while they have been found non-mutagenic in the bacterial test systems [Yoshikawa et al. 1983, Zeiger et al. 1985]. Indications of DNA damage in human mucosal cells and lymphocytes) have, however, been detected [Kleinsasser et al. 2000, 2001].

The human tolerable daily intakes (TDIs) proposed by different scientific bodies range from $0.020 \mathrm{mg} \mathrm{kg} \mathrm{bw}^{-1} \mathrm{day}^{-1}$ (infants) to $0.050 \mathrm{~kg} \mathrm{bw}^{-1} \mathrm{day}^{-1}$ for the di (2-ethyl-hexyl) phthalate, which is generally regarded as the most toxic [Heudorf et al. 2007]. Although the concentrations migrating from paper and board to the foodstuffs would not reach the TDIs proposed the possibility of amounts approaching the cytotoxic levels cannot be excluded.

\section{The cytotoxic activity of FWAs and 2,4-diaminotoluene}

Both FWAs and especially 2,4-diaminotoluene displayed a more marked toxicity in the hepatic cells than in the Hep-2 cell line, this being an example of metabolic activation. This (together with the opposite results obtained with DiPNS and phthalates) illustrates the need to include cell lines with different metabolic capacities in toxicological test batteries in order to get a complete understanding of the bioactivities of the substances tested.

The FWAs used in the studies are stilbene derivatives. Natural stilbenes have antimicrobial and also cytotoxic effects [Välimaa et al. 2007], but are not known to be particularly toxic to humans, indeed beneficial effects (antitumorigenic and antiartherosclerotic activities, protection against type II diabetes) have been associated with resvertrol, a natural stilbene [Jang et al. 1997; Pace-Aciak et al., 1995; Lagogue et al., 2006]. In the studies reported here both disulpho and tetrasulphostilbenes were cytotoxic in all the test systems. 
Tests for any bleeding of FWAs are frequently conducted by industry to ensure quality. Tests can be either optical (i.e. visual) or chemical (e.g. LC-FLD. Unlike many substances which might migrate from FCMs into food, FWAs are more soluble in water than fat. Migration of the water-soluble FWAs would be expected to be more extensive into moist foods rather than fatty foods. European Standard EN 648:2003 is concerned with the determination of the fastness of fluorescent whitened paper and board [EN 648:2003]. The paper/board sample is brought into contact with a glass fibre paper which has been saturated with the test fluid (water, $3 \%$ acetic acid, $5 \mathrm{~g} \mathrm{~L}^{-1}$ sodium carbonate or olive oil). Transfer is assessed using reference discs made using an FWA standard at 0, 4.2, 11.3, 44 and $177 \mu \mathrm{g} \mathrm{dm}^{-2}$. These represent grades 1 to 5. Grade 1 is descried as good colour fastness, grade 5 is described as poor colour fastness. The test conditions with a liquid simulant are rather severe.

Nevertheless the middle calibration standard, Grade 3, is equal to a transfer of $11.3 \mu \mathrm{g} \mathrm{dm}^{-2}$. which is just $68 \mathrm{ppb}$ for the standard EU cube of $1 \mathrm{~kg}$ food in direct contact with $6 \mathrm{dm}^{-2}$ of packaging. When FWAs are surveyed [e.g. MAFF 1995] the conclusions are that even assuming total mass transfer there is no safety concerns. Therefore, the possibility of a consumer being accidentally exposed to cytotoxic concentrations of these substances, even in a worst case scenario assuming total migration to fatty foodstuff or drink, can be discounted.

2,4-Diaminotoluene was used as an example of primary aromatic amines (PAAs) that can be environmental pollutants. These chemicals are not expected to contaminate primary paper and board production but they can arise as contaminants from the use of certain aromatic isocyanates in adhesives or as impurities in some azo-dyes. For this reason, food contact materials are often tested for the release of PAAs using a colormetric test with a requirement 
that PAAs should be not detectable at $10 \mu \mathrm{g} \mathrm{kg}^{-1}$ food or food simulant. The value of $10 \mu \mathrm{g}$ $\mathrm{kg}^{-1}$, as the limit of the detection of the method, is the established limit for plastics because it has been decided that this type of substance should not migrate at all. The value is not linkedto nor derived-from any quantitative measure of toxic potency of PAAs. This value of $10 \mu \mathrm{g}$ $\mathrm{kg}^{-1}$ is more than a thousand times less than the toxic doses of $0.1 \mathrm{mM}$ observed here in the most sensitive cell lines.

\section{Experiences from the spiked samples}

Acrylamide spiked extracts

The purpose of these experiments was to check the effects of the background material in the extracts on the cytotoxicity assays acrylamide serving as a representative test substance. As there was no difference in the cytotoxic response between acrylamide dissolved either in water or ethanol or in the corresponding extracts of paper and board, the paper and board extractives apparently did not interfere with the assays. This conclusion should, however, be made with the reservation that the toxic concentrations are considerably higher than those that could be expected to occur in paper and board.

\section{$B(a) P$ spiked extracts}

The experiments were performed in order to find out the possible interference of two toxicants in the case when the toxic effects requires metabolic transformation by the target cells. For that purpose the known genotoxic substance B(a)P was tested at various concentrations in the Comet assay with the hepatic cell line HepG2 in the presence of DiPNs. The observed effects were minor (Figures 1 and 2) and could be considered as background variation inherent to the test. $\mathrm{B}(\mathrm{a}) \mathrm{P}$ was clearly genotoxic, irrespective of the extract into which it was dissolved or of the presence of DiPNs. Thus the system appears to be robust tolerating a considerable amount of metabolic interference. 


\section{The role of the identified substances in the toxicities of the NSP4 and NSP5 extracts}

On the basis of the results reported here, the most cytotoxic substances present in significant amounts in the 50-fold concentrated NSP4 extracts would be DiPNs $\left(218 \mu \mathrm{g} \mathrm{mL}^{-1}\right)$ and phthalates $\left(192 \mu \mathrm{g} \mathrm{mL}^{-1}\right)$. At the clearly cytotoxic concentrations of the extract $[0.5 \%$, Bradley et al., 2008], these substances would have been present at quantities of around 1.09 $\mu \mathrm{g} \mathrm{mL} L^{-1}$ and $0.96 \mu \mathrm{g} \mathrm{mL}^{-1}$. When compared to the data presented in table 3 , these concentrations, being close to the $\mathrm{EC}_{20}$ values of some of the test systems, probably contribute to the cytotoxicity of NSP4. However, their amounts in the toxic doses of concentrated NSP5 extract are $0.19 \mu \mathrm{g} \mathrm{mL}^{-1}$ and $0.45 \mu \mathrm{g} \mathrm{mL}^{-1}$, respectively, [Bradley et al. 2008] and neither of them alone would suffice to give a very potent response in the RNAsynthesis inhibition assays characteristic of NSP5.

No actual cytotoxicity studies on 1-methyl-2-pyrrolidinone, the most abundant identified compound of NSP5, has apparently been done, However, since this compound has been used to stimulate the differentiation of cultured kidney cells at concentrations of $25 \mathrm{mM}$ (or 2475 $\mu \mathrm{g} \mathrm{mL}^{-1}$ ) [Lever, 1979] it is unlikely to cause cytotoxicity at the concentrations reported here.

Dehydroabietic acid proved to be totally non cytotoxic at the tested concentrations, and therefore it or its derivatives probably do not have a role in the cytotoxicity of the extract.

While the combined effects of DiPNs and phthalates undoubtedly contribute to the cytotoxicity of the NSP extracts, the nature of the genotoxic principle in NSP4, given the absence of genotoxicity of either phthalates or DiPNs remains unsolved. There are apparently no public genotoxicity reports on DiPNs, while the non-mutagenicity of phthalates in bacterial systems has been confirmed in several studies, as pointed out above. The other 
substances present in NSP4 are present in small quantities and are either tested non-mutagens [benzophenone, bisphenol A, Chhabra, 2000; Schweikl et al. 1998, ] or their genotoxicity profile is unknown.

The difficulty to identify the compounds responsible for the observed toxicity of extracts of food contact materials is general. In a recent report [Simat et al. 2009] the Neutral Red UptakeTest (NRU) which measures cytotoxicity as an inhibition of the uptake of a red dye in a cell culture of Hep G2 cells was used along with in-depth chemical analysis for a comprehensive evaluation of the total migrate. This merits some detailed discussion because they were testing not paper/board as done here but can coatings and complex plastic laminates.

When testing the total migrate obtained from an epoxyanhydride can coating using $95 \%$ ethanol for 4 hours at $60{ }^{\circ} \mathrm{C}$, only about $0.5 \%$ of the inhibition could be attributed to regulated substances such as bisphenol A, bisphenol A diglycidyl ether and its hydrolysis product. Further chemical analysis revealed a major contribution (a further 18\%) by cyclo-diBADGE. There was no inhibition by the fraction with MW above 1000 . This means that $80 \%$ of the NRT inhibition effect was caused by substances that remained unidentified.

A similar picture was revealed for the total migrate prepared using $95 \%$ ethanol for 4 hours at $60{ }^{\circ} \mathrm{C}$ on a plastic laminate. The laminate structure was complex and was Polyethylene // Adhesive // Polyethyleneterephthalate // Aluminium (vacuum deposited) // Ink // Nitrocellulose lacquer. Chemical analysis identified twelve substances and when these were tested in the NRT eight were inactive and four accounted for $33 \%$ of the inhibition seen for the total migrate. When these four substances were tested not individually but in combination 
there was a $+40 \%$ enhancement so that in combination they accounted for about $46 \%$ of the total inhibition seen. This still left more than $50 \%$ of the cytotoxicity caused by unidentified substances. As with the example of the can coating, this large missing fraction emphasises the need for using bioassays to help pinpoint and then identify any potentially hazardous substances.

Simat et al., [2009] commented that some regulated substances show no response in the NRU assay and for some substances the NR uptake has insufficient sensitivity to test at the specific migration limit (SML). There are several reasons for that.

First, the NRU reveals only one mechanism of toxicity. The mechanistic principle of the test is that is substances that damage the lysosomal membrane then inhibit the uptake of NR. In reality there are many mechanisms of toxicity and this reinforces the need for a battery of tests as recommended here. Additionally, the sensitivity of cytotoxicity assays depends also of the cell line used, as pointed out above. Ideally, both hepatic cell lines capable of inactivating and in some cases activating xenobiotics and metabolically less competent cells (like Hep-2 cells used here) should be used in the testing programme.

Second, a regulated substance often has an SML set based not on any toxicity seen but on the extent of the data package submitted [Barlow, 2009]. For the most common SML restrictions of $50 \mathrm{ppb}$ and $5 \mathrm{ppm}$ there would have been no toxicity observed in the tests evaluated by EFSA and the SCF before them.

Finally, this intrinsic lack of sensitivity was compounded by a low tolerance of the NRU to the carrier solvent used (DMSO, dimethylsulfoxide) and only up to $1 \%$ could be added to the 
cell culture. DMSO is a polar, water-miscible, solvent that has limited capacity to redissolve the total migrate obtained using a large volume of hot ethanol. Also, the total migrate from a can coating and from a plastic laminate will be rather non-polar in character and not well suited for DMSO. Solubility was less of a limiting factor for testing paper/board and the total migrate could for example be concentrated 10-fold and applied to the bioassays without problems [Bradley et al., 2008; 2009]. 


\section{CONCLUSIONS}

Cytotoxicity and genotoxicity assays can be used to assess the consumer safety of paper and board. While the toxic substances can in some cases be tentatively retrospectively identified, the large number of substances that can be present in the extracts and their eventual interactions make the pinpointing of the cyto- or genotoxic activities to individual substances difficult or impossible. The sensitivities of the different assays are variable and also the tolerance of the biological test systems to solvents used in the extraction is typically low. This necessitates the use of combination of different tests, including the use of cell lines with variable metabolic capacities, and often concentration steps for the samples.

\section{ACKNOWLEDGEMENTS}

This work was funded by the European Union under contract QLK1-2001-00930 "BIOSAFEPAPER - Application of bioassays for safety assessment of paper and board for food contact" and by a consortium of 16 paper and board making companies. The findings and the conclusions in this paper are the responsibility of the authors alone and they should not be taken to represent the opinion of the European Commission or any paper and board making companies 


\section{REFERENCES}

Andersson M. A., Mikkola R., Helin J., Andersson M.C., Salkinoja-Salonen M. 1998. A novel sensitive bioassay for detection of Bacillus cereus emetic toxin and related depsipeptide ionophores. Applied and Environmental Microbiology 64:1338-43.

Barlow, S. M. (2009) Risk assessment of food contact materials: Past experience and future challenges. Proceedings of the 4th Int. Symp. on Food Packaging, Prague, Nov. 2008. Food Additives and Contaminants, submitted.

Bebiolka H. and Dunkel, K. 1997. Übergang von di-iso-propyl-naphthalin aus kartonverpackungen auf lebensmittel (Passage of diisopropylnaphthalene from cardboard packing to food). Lebensmittelchemie, 1997, 51, 53-61.

Bradley, E. L., Honkalampi-Hämäläinen, U., Weber, A., Andersson, M. A., Bertaud, F., Castle, L., Dahlman, O., Hakulinen, P., Hoornstra, D., Lhuguenot, J-C., MakI-Paakkanen, J., Salkinoja-Salonen, M., Speck, D. R., Severin, I., Stammati, A., Turco, L., Zucco, F. and von Wright, A. 2008. The BIOSAFEPAPER project for in vitro toxicity assessments: Preparation, detailed chemical characterisation and testing of extracts from paper and board samples. Food and Chemical Toxicology, 46, 2498-2509.

Bradley, E. L., Honkalampi-Hämäläinen, U., Andersson, M. A., Bertaud, F., Castle, L., Dahlman, O., Hakulinen, P., Hoornstra, D., Lhuguenot, J-C., Maki-Paakkanen, J., Severin, I., Stammati, A., Salkinoja-Salonen, M., Speck, D. R., Traussnig, H., Turco, L., Weber, A., Zucco, F. and von Wright, A. 2009. Test procedures for obtaining representative extracts 
suitable for reliable in vitro toxicity assessment of paper and board intended for food contact. Food Additives and Contaminants, submitted.

Chhabra, R. S. 2000. NTP technical report on the toxicity studies of benzophenone (CAS No. 119-61-9). Administered in feed to F344/N rats and B6C3F mice. Toxicity Report Series 61: $1-53$.

COE 2002. Council of Europe Resolution A.P. . 2002. 1 on paper and board materials and articles intended to come into contact with foodstuffs.

EN 648:2003. Paper and board intended to come into contact with foodstuffs Determination of the fastness of fluorescent whitened paper and board. European Standard EN 648:2003.

FSA 2002. Paper and board packaging: not likely to be a source of acrylamide in food. Food Survey Information Sheet 27/02. Food Standards Agency, London, UK, 2002.

Heudorf, U., Mersch-Sunderman, V. and Angerer, J. 2007. Phthalates: Toxicology and exposure. International Journal of Hygiene and Environmental Health 210: 623-634.

Höke, H. and Zellerhoff, R. 1998. Metabolism and toxicity of diisopropylnahthalene as compared to naphthalene and monoalkyl naphthalenes: a minireview. Toxicology 126: 1-7. 
Jang, M., Cai, L., Udeani, G. O., Slowing, K. V., Thomas, C. F.; Beecher, C. W. W.; Fong, H. H. S.; Farnsworth, N. R.; kinghorn, A. D., Mehta, R. G., Moon, R. C. and Pezzuto, J. M. 1997. Cancer chemopreventive action of resveratrol, a natural product derived from grapes. Science, 275: 218-220.

Kleinsasser, N. H., Kastenbauer, E. R., Weissacher, H., Muenzenrieder, R .K. and Harréus, U. A. 2000. Phthalates demonstrate genotoxicity on human mucosa of the upper aerodigestive tract. Environmental and Molecular Mutagenesis 35: 9 - 12.

Kleinsassner, N. H., Wallner, B. C., Kastenbauer, E. R., Weissacher, H. and Harréus, U. A. 2001. Genotoxicity of di-butyl-phthalate and di-isobutyl-phthalate in human lymphocytes and mucosal cells. Teratogenesis, Carcinogenesis, and Mutagenesis 21: 189-196.

Lagouge, M., Argmann, C., Gerhart-Hines. Z., Meziane, H., Lerin, C., Daussin, F., Messadeq, N., Milne „J., Lambert, P., Elliott, P., Geny, B., Laakso, M., Puigserver, P. and Auwerx, J. 2006. Resveratrol improves mitochondrial function and protects against metabolic disease by activating SIRT1 and PGC-1 $\alpha$. Cell 127: 1 - 14.

Lever, J.E. 1979. Inducers of mammalian cell differentiation stimulate dome formation in a differentiated kidney epithelial cell line (MDCK). Proceedings of the National Academy of Sciences USA 76: 1323 - 1327.

MAFF 1995. Fluorescent whitening agents. Food Surveillance Information Sheet,47, 1995. Ministry of Agriculture Fisheries and Food, London, UK 
MAFF 1999. Diisopropylnaphthalenes in food packaging made from recycled paper and board. Food Surveillance Information Sheet, 169, 1999. Ministry of Agriculture Fisheries and Food, London, UK.

Maron, D.M. and Ames, B. N., 1983. Revised methods for the Salmonella mutagenicity test. Mutation Research 113: 173-215.

Ozaki, A., Yamaguchi, Y., Fujita, T., Kuroda, K. and Endo, G. 2005. Safety assessment of paper and board food packaging: Chemical analysis and genotoxicity of possible contaminants in packaging? Food Additives and Contaminants, 22, 1053-1060.

Pace-Asciak, C. R., Hahn, S., Diamandis, E. P., Soleas G. and Goldberg, D. M. 1995. The red wine phenolics trans-resveratrol and quercetin block human platelet aggregation and eicosanoid synthesis: implication for protection against coronary heart disease. Clinica Chimica Acta 235: 207-219.

RKS GmbH (Duisburg, DE). 1998. DIPN (diisopropylnaphthalene) technical information (data sheet) July 1998.

Roberts, J. C. (Editor). 1991. Paper Chemistry, Blackie \& Son, Glasgow \& London, 1991. ISBN 0-2 16-92909- 1.

Schweikl, H., Schmalz, G. and Rackenbrandt, K. 1998. The mutagenic activity of unpolymerized resin monomers in Salmonella typhimurium and V79 cells. Mutation Research 415:119-130. 
Severin, I., Dahbi, L., Lhuguenot, J-C., Andersson, M. A., Hoornstra, D., Salkinoja-Salonen, M., Turco, L., Zucco, F., Stammati, A., Dahlman, O., Castle, L., Savolainen, M., Weber, A., Honkalampi-Hämäläinen, U. and Von Wright, A. 2005. Safety assessment of food-contact paper and board using a battery of short-term toxicity tests: European Union BIOSAFEPAPER project. Food Additives \& Contaminants, 22, 1032 - 1041.

Simat, J. T. et al. (2009). Use of biotests in the analysis of migrants from coatings and plastic laminates. Proceedings of the 4th Int. Symp. on Food Packaging, Prague, Nov. 2008. Food Additives and Contaminants, submitted.

Sturaro, A., Parvoli, G., Rella, R., Bardati S. and Doretti, L. 1994. Food contamination by diisopropylnaphthalenes from cardboard packages. International Journal of Food Science \& Technology 29: 593-603.

Välimaa, A-L., Honkalampi-Hämäläinen, U., Pietarinen, S., Willför, S., Holmbom, B. and von Wright, A. 2007.Antimicrobial and cytotoxic knotwood extracts and related pure compounds and their effects on food-associated microorganisms. International Journal of Food Microbiology. 115: 235-243.

von Wright, A. 2007. Safety assessment of paper and board used in food packaging. in: 'Chemical migration and food contact materials'. pp. 333-345, K. A. Barnes, R. Sinclair and D. Watson, (eds). Woodhead Publishing, Cambridge UK, ISBN-13: 978-1-84569-029-8. 
Zeiger, E., Haworth, S., Mortelmans, K. and Speck, W. 1985. Mutagenicity testing of di(2ethylhexyl)phthalate and related chemicals in Salmonella. Environmental Mutagenesis 7: 213 $-232$.

Zhang, K., Noonan, G. O. and Begley, T. H. 2008. Determination of 2,6diisopropylnaphthalene (DiPN) and $n$-dibutylphthalate (DBP) in food and paper packaging materials from US marketplaces. Food Additives \& Contaminants: Part A, 25, 1416 - 1423. 
Legends to figures.

\begin{abstract}
Figure 1. The absence of interaction of DiPNs on genotoxic effect of benzo(a)pyrene (B[a]P) spiked ethanol extract of NSP4 in comet assay.
\end{abstract}

Figure 2. The absence of interaction of DiPNs on genotoxic effect of benzo(a)pyrene (B[a]P) spiked water extract of NSP11 in comet assay. 
Table 1. The quantitatively most important identified compounds in ethanol extracts of board samples NSP4 and NSP5 (Bradley et al. 2008)

\begin{tabular}{|l|c|c|}
\hline \multirow{2}{*}{ Compound } & \multicolumn{2}{|c|}{ Concentration ( $\mu$ g ml-1) } \\
\cline { 2 - 3 } isomers & NSP4 & 37 \\
\hline Diisopropylnaphthalene & 218 & 116 \\
\hline C15 - 29 n-alkanes & 154 & 65 \\
\hline Diisobutyl phthalate & 37 & 20 \\
\hline Dibutyl phthalate & 29 & 3,4 \\
\hline Di(2-ethylhexyl)phthalate & 5.5 & 290 \\
\hline Other phthalates & not detected & 24.5 \\
\hline 1-Methyl-2-pyrrolidininone & 40.9 & 565 \\
\hline Dehydroabietic acid and & & \\
\hline derivatives & & \\
\hline Sum & & \\
\hline Fraction of the total amount of & & \\
\hline
\end{tabular}


1

Table 2. Cytotoxic and genotoxic properties of wood-related substances and model contaminants.

\begin{tabular}{|c|c|c|c|c|c|c|c|}
\hline \multirow[b]{3}{*}{$\begin{array}{l}\text { Chemical or } \\
\text { extract }\end{array}$} & \multirow[b]{3}{*}{$\begin{array}{l}\text { Concentration } \\
\text { range }\end{array}$} & \multicolumn{5}{|c|}{ Cytotoxicity } & \multirow{3}{*}{$\begin{array}{c}\text { Genotoxicity } \\
\\
\text { Ames test }{ }^{2}\end{array}$} \\
\hline & & \multirow{2}{*}{$\begin{array}{c}\text { Boar } \\
\text { spermato- } \\
\text { zoan } \\
\text { motility } \\
\text { inhibition }\end{array}$} & \multirow{2}{*}{$\begin{array}{c}\text { RNA- } \\
\text { synthesis } \\
\text { inhibition } \\
\text { (HepG2 } \\
\text { cells) }\end{array}$} & \multicolumn{2}{|c|}{ Immediate cytotoxicity } & \multirow[b]{2}{*}{$\begin{array}{l}\text { Comet } \\
\text { assay }\end{array}$} & \\
\hline & & & & \begin{tabular}{|c||} 
Hepa- \\
1c1c7 cells
\end{tabular} & $\begin{array}{l}\text { HEp-2 } \\
\text { cells }\end{array}$ & & \\
\hline $\begin{array}{l}\text { Dehydroabietic } \\
\text { acid }\end{array}$ & $0.25-2 \mathrm{mg} / \mathrm{ml}$ & $\mathrm{NE}^{3}$ & $\mathrm{NE}$ & $\mathrm{NE}$ & $\mathrm{NE}$ & \begin{tabular}{|c|} 
neg \\
$0.1 \mathrm{mgmL}^{-1}$
\end{tabular} & $\begin{array}{c}\text { neg } \\
800 \mu \mathrm{g}\end{array}$ \\
\hline $\begin{array}{l}\text { Spruce wood } \\
\text { (ethanol extract) }\end{array}$ & $0.25-2 \%$ & $\mathrm{NE}$ & $\begin{array}{l}\mathrm{EC}_{50} \approx 1.3 \\
\mathrm{EC}_{40} \approx 1.0\end{array}$ & $\mathrm{NE}$ & $\mathrm{NE}$ & negative & $\mathrm{NT}^{4}$ \\
\hline $\begin{array}{l}\text { Spruce wood } \\
\text { (water extract) }\end{array}$ & $1-90 \%$ & $\mathrm{NE}$ & $\begin{array}{l}\mathrm{EC}_{50} \approx 33 \\
\mathrm{EC}_{40} \approx 25\end{array}$ & $\mathrm{NE}$ & $\mathrm{EC}_{50} \approx 20$ & Negative & NT \\
\hline Acrylamide & $1-16 \mathrm{mM}$ & 5 & $\begin{array}{l}\mathrm{EC}_{50} \approx 4 \\
\mathrm{EC}_{40} \approx 3.2\end{array}$ & $\begin{array}{c}\mathrm{EC}_{50} \approx 2.5 \\
\mathrm{EC}_{20} \approx 2\end{array}$ & $\begin{array}{l}\mathrm{EC}_{50} \approx 4 \\
\mathrm{EC}_{20} \approx 1\end{array}$ & $\begin{array}{l}\text { Positive } \\
1.5 \mathrm{mM}\end{array}$ & $\begin{array}{c}\text { neg } \\
10 \mathrm{mg}\end{array}$ \\
\hline $\begin{array}{l}\text { 2,4-Diamino- } \\
\text { toluene }\end{array}$ & $1-45 \mathrm{mM}$ & 1 & $\begin{array}{l}\mathrm{EC}_{50} \approx 4.3 \\
\mathrm{EC}_{40} \approx 2.4\end{array}$ & $\begin{array}{c}\mathrm{EC}_{50} \approx 1 \\
\mathrm{EC}_{20} \approx 0.1\end{array}$ & $\begin{array}{l}\mathrm{EC}_{50} \approx 22 \\
\mathrm{EC}_{20} \approx 5\end{array}$ & $\begin{array}{c}\text { Positive } \\
1 \mathrm{mM}\end{array}$ & $\begin{array}{l}\text { Positive } \\
\qquad 5 \mu \mathrm{g}\end{array}$ \\
\hline $\begin{array}{l}\text { Phthalate } \\
\text { mixture }\end{array}$ & $7-150 \mu \mathrm{gmL}^{-1}$ & 8 & $\begin{array}{l}\mathrm{EC}_{50} \approx 99 \\
\mathrm{EC}_{40} \approx 83\end{array}$ & $\begin{array}{l}\mathrm{EC}_{50} \approx 13 \\
\mathrm{EC}_{20} \approx 9\end{array}$ & $\begin{array}{c}\mathrm{EC}_{50} \approx 2.5 \\
\mathrm{EC}_{20} \approx 2\end{array}$ & \begin{tabular}{|c|} 
Negative \\
$800 \mu \mathrm{gmL}^{-1}$
\end{tabular} & $\begin{array}{l}\text { Negative } \\
500 \mu \mathrm{g}\end{array}$ \\
\hline $\begin{array}{l}\text { Diisopropyl- } \\
\text { naphthalene } \\
\text { isomers(DiPNs) }\end{array}$ & $\underset{1}{2.5-74 \mu \mathrm{gmL}}$ & 2.5 & $\begin{array}{l}\mathrm{EC}_{50} \approx 20 \\
\mathrm{EC}_{40} \approx 35\end{array}$ & \begin{tabular}{|l|}
$\mathrm{EC}_{50} \approx 15$ \\
$\mathrm{EC}_{20} \approx 10$
\end{tabular} & $\begin{array}{l}\mathrm{EC}_{50} \approx 13 \\
\mathrm{EC}_{20} \approx 1.4\end{array}$ & \begin{tabular}{|l|} 
Negative \\
$80 \mu \mathrm{gmL}^{-1}$ \\
\end{tabular} & $\begin{array}{l}\text { Negative } \\
500 \mu \mathrm{g}\end{array}$ \\
\hline Disulpho stilbene & $0.1-12 \mu \mathrm{gmL}$ & 0.2 & $\begin{array}{l}\mathrm{EC}_{50} \approx 0.7 \\
\mathrm{EC}_{40} \approx 0.5\end{array}$ & $\begin{array}{l}\mathrm{EC}_{50} \approx 1.4 \\
\mathrm{EC}_{20} \approx 0.9\end{array}$ & $\begin{array}{l}\mathrm{EC}_{50} \approx 5.0 \\
\mathrm{EC}_{20} \approx 0.1\end{array}$ & Negative & $\begin{array}{l}\text { Negative } \\
500 \mu \mathrm{g}\end{array}$ \\
\hline $\begin{array}{l}\text { Tetrasulpho } \\
\text { stilbene }\end{array}$ & $1-46 \mu \mathrm{gmL}^{-1}$ & $\overline{0.4}$ & $\begin{array}{l}\mathrm{EC}_{50} \approx 5.6 \\
\mathrm{EC}_{40} \approx 3.7\end{array}$ & $\begin{array}{l}\mathrm{EC}_{50} \approx 5.5 \\
\mathrm{EC}_{20} \approx 2\end{array}$ & $\begin{array}{l}\mathrm{EC}_{50} \approx 19 \\
\mathrm{EC}_{20} \approx 1\end{array}$ & Negative & $\begin{array}{l}\text { Negative } \\
500 \mu \mathrm{g}\end{array}$ \\
\hline
\end{tabular}

\footnotetext{
${ }^{1}$ The concentration on the box is the highest tested if different from the top concentration given in the second column.
} 
2 The concentrations used in Ames tests were the highest amount per plate not causing the growth inhibition of the tester strains (see text)

${ }^{3}$ No or only marginal effects even at the highest tested concentration

${ }^{4} \mathrm{nt}=$ not tested 
Table 3 The toxicities of acrylamide-spiked paper and board extracts

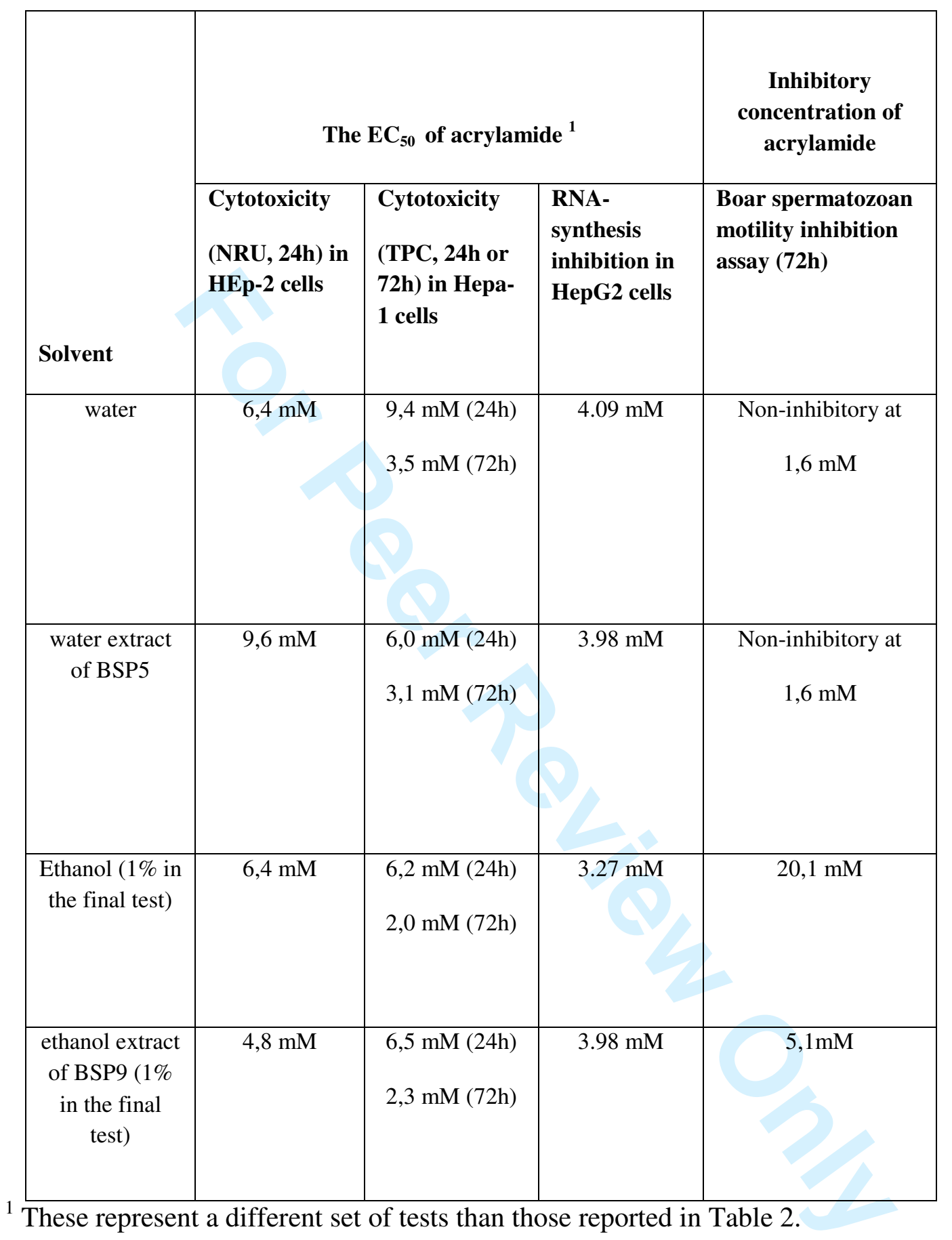


Figure 1.

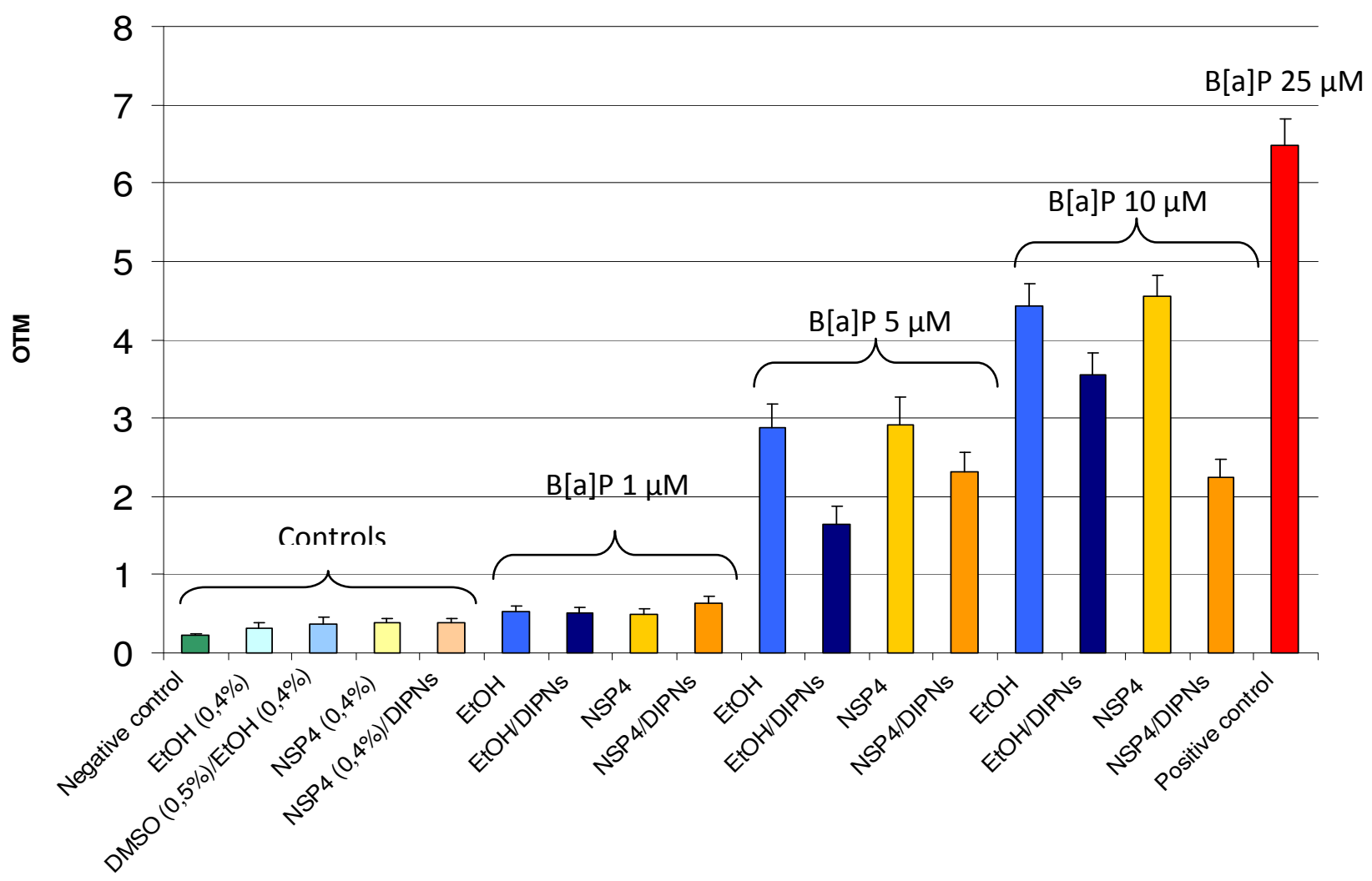


Figure 2.

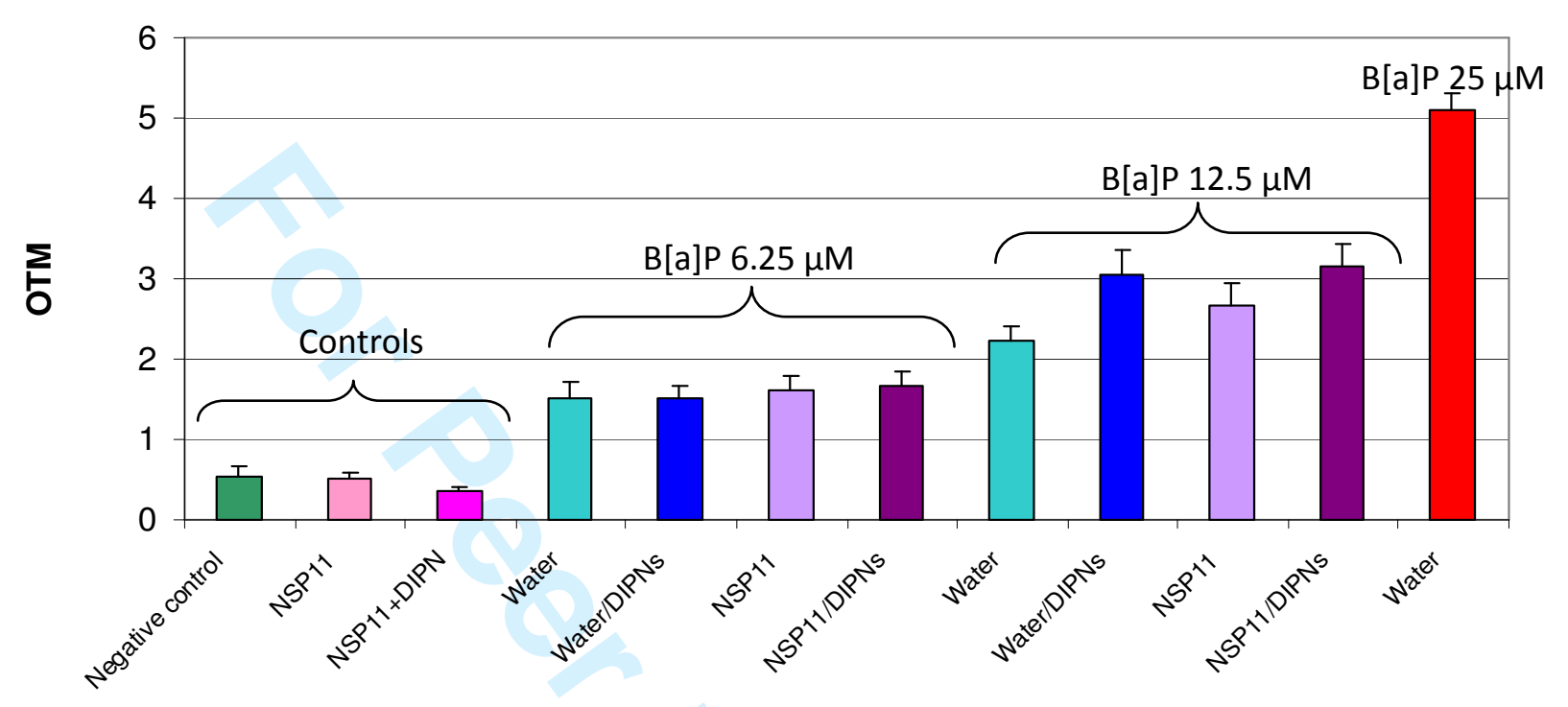

